\title{
Nucleoside diphosphate kinase isoforms regulated by phytochrome A isolated from oat coleoptiles
}

\author{
Anna Hetmann $\bowtie$ and Stanisław Kowalczyk \\ Nicolaus Copernicus University, Institute of General and Molecular Biology, Department of Biochemistry, \\ Toruń, Poland
}

Received: 19 November, 2008; revised: 06 February, 2009; accepted: 24 February, 2009

available on-line: 04 March, 2009

\begin{abstract}
Nucleoside diphosphate kinase (NDPK) (EC 2.7.4.6), the enzyme transferring the phosphate residue from ATP to nucleoside diphosphates, is localized mainly in the cytoplasm and mitochondria and in smaller amounts in cell nuclei and the microsomal fraction. Exposure of etiolated oat seedlings to red light causes an increase of the enzyme activity by about $42 \%$ in nuclear fraction, $7 \%$ in etioplastic and $14 \%$ in postetioplastic fraction. Endogenous phytochrome A, as visualized by an immunochemical method, translocates from the cytoplasm into the nucleus upon red, farred or white light activation. Nuclei purified from oat seedlings contain two, and the postnuclear fraction four easily separated forms of NDPK. One of the nuclear isoforms $\left(I_{n}\right)$ and one isoform isolated from the postnuclear fraction ( $\left.\mathrm{II}_{\mathrm{pn}}\right)$ are activated by red light in the presence of phytochrome A purified from etiolated oat coleoptiles. Both phytochrome A-activated NDPKs purified to electrophoretic homogeneity have the same molecular mass (17-18 kDa) determined by SDS/

PAGE. Both enzymes in the native form have similar molecular masses (71 and $63 \mathrm{kDa}$ ).
\end{abstract}

Keywords: NDPK (nucleoside diphosphate kinase), phytochrome A, NDPK isoforms, phytochrome A nuclear import

\section{INTRODUCTION}

Nucleoside diphosphate kinase (NDPK) (EC 2.7.4.6) is a phosphotransferase transferring the phosphate residue from nucleoside triphosphates (NTP), mainly ATP, to 5'-nucleoside diphosphates (NDP) according to the following equation:

$\mathrm{ATP}+\mathrm{E} \Leftrightarrow \mathrm{E}-\mathrm{P}+\mathrm{ADP}$

$\mathrm{E}-\mathrm{P}+\mathrm{NDP} \Rightarrow \mathrm{E}+\mathrm{NTP}$

NDPK, discovered over 50 years ago in yeast and in pigeon muscle cells (Parks \& Agarwal, 1973; Lacombe et al., 2000), plays a key role in the maintenance of physiological concentrations of ribo- and deoxyribonucleotide triphosphates in the cell. In recent years, interest in this enzyme has increased es- pecially after cloning of the awd gene from Drosophila melanogaster and the human NM23 gene (Lacombe et al., 2000). The NDPK isoforms encoded by these genes fulfill functions totally different from those that were previously ascribed to the enzyme. The progress of investigation in the succeeding years has confirmed that some NDPK isoforms from animal tissues are involved in the regulation of transcription, others in cell differentiation and yet others play the role of phosphotransferases transferring the phosphate residue to proteins (Kikkawa et al., 1990; Bominaar et al., 1993; Kimura et al., 2000; 2003; Otero, 2000; Baillat et al., 2002; Narayanan \& Ramaswami, 2003).

The results of investigations performed on plant material link the role of NDPK with plant responses to stress factors such as wounding (Harris et

\footnotetext{
${ }^{\square}$ Corresponding author: Anna Hetmann, Nicolaus Copernicus University, Institute of General and Molecular Biology, Department of Biochemistry, 87-100 Toruń, Poland; e-mail: ahetmann@umk.pl

Abbreviations: ARR4, Arabidopsis response regulator4; Aux/IAA, early auxin gene; Cry1, cryptochrome 1; ELF, early flowering; HFR/REP1/RSF1, long hypocotyls in far-red/reduced phytochrome signaling 1/reduced sensitivity to far-red light; NDPK, nucleoside diphosphate kinase; NDP, nucleoside diphosphate; PIFs, phytochrome interacting factors; PKS1, phytochrome kinase substrate 1; Pr and Pfr, red and far-red absorbing forms of phytochrome, respectively.
} 
al., 1994), thermal stress (Moisyadi et al., 1994; Leung \& Hightower, 1997; Hurkman et al., 1998; Barthel \& Walker, 1999; Escobar Galvis et al., 2001), oxidative stress (Moon et al., 2003; Yang et al., 2003) and UV-B (Zimmermann et al., 1999). Moreover, results of several experiments performed on pea have shown that red light activates NDPK phosphorylation (Tanaka et al., 1998). Research using the yeast two-hybrid system has confirmed the physical interaction of recombinant phytochrome A with one of the NDPK isoforms from Arabidopsis thaliana, suggesting that the NDPK2 isoform functions in the phytochrome signal transduction pathways (Choi et al., 1999). Results of the most recent investigations indicate that NDPK2 also participates in auxin signaling playing a role in phytohormone transport (Choi et al., 2005), and cytosolic NDPK is involved in growth and cell division (Dorion et al., 2006), pea mitochondrial NDP kinase (NDPK3) cleaves DNA and RNA (Hammargren et al., 2007). A similar role is possible for NDPK2 localized in chloroplasts and supposedly associated with nucleoids (Bölter et al., 2007). The aim of our investigation was the separation of NDPK isoforms localized in the nucleus and the postnuclear fraction obtained from etiolated oat seedlings and identification and purification of isoforms subjected to regulation by red light via phytochrome A.

\section{MATERIALS AND METHODS}

Plant material. The plant material used in the investigations were 5-day seedlings of the oat variety Chwat, growing in the dark at $25^{\circ} \mathrm{C}$.

Separation of subcellular fractions. Excised coleoptiles were homogenized manually in a chilled mortar inlaid with a nylon net in a homogenizing solution containing: $10 \mathrm{mM}$ Tris/ $\mathrm{HCl}$ buffer, $\mathrm{pH}$ 7.5, $0.3 \mathrm{M}$ sucrose, $10 \mathrm{mM} \mathrm{CaCl}, 10 \mathrm{mM} \mathrm{MgCl}$ and 10 $\mathrm{mM}$ 2-mercaptoethanol (at a ratio of $6 \mathrm{ml}$ solution per $1 \mathrm{~g}$ tissue). The homogenate was filtered through four layers of cheesecloth and fractionated by centrifugation. The crude nuclear fraction was obtained after $15 \mathrm{~min}$ of centrifugation at $700 \times \mathrm{g}$. The obtained supernatant was centrifuged for $2 \mathrm{~min}$ at $6000 \times g$ in order to sediment the etioplastic fraction according to Evans and Smith (1976). The obtained supernatant, subsequently designated as the "postetioplastic" fraction, was centrifuged for $20 \mathrm{~min}$ at $20000 \times g$ in order to sediment the mitochondrial fraction, and the obtained supernatant was centrifuged in an ultracentrifuge at $60000 \times g$ for $60 \mathrm{~min}$ in order to sediment the microsomal fraction. The obtained supernatant was treated as the soluble protein fraction (cytosolic fraction).

Purification of cell nuclei. The crude nuclear fraction suspended in a small volume $(1-10 \mathrm{ml})$ of homogenizing buffer was layered on a solution containing $0.3 \mathrm{M}$ sucrose and $40 \%$ glycerol prepared in $10 \mathrm{mM}$ Tris/ $\mathrm{HCl}$ buffer, $\mathrm{pH}$ 7.5, containing $10 \mathrm{mM}$ $\mathrm{KCl}, 10 \mathrm{mM} \mathrm{MgCl}$ and $10 \mathrm{mM}$ 2-mercaptoethanol placed in centrifuge tubes. Centrifugation at $700 \times g$ for $15 \mathrm{~min}$ allowed the sedimentation of nuclei. The pellet of purified nuclei was suspended in homogenization medium or in $10 \mathrm{mM}$ Tris/ $\mathrm{HCl}$ buffer, $\mathrm{pH}$ 7.5 , containing $10 \mathrm{mM} \mathrm{MgCl} 2$. The nuclear protein extract was obtained by sonication of the purified nuclei using an ultrasonic disintegrator (type UD-20 Techpan). Samples not exceeding $5 \mathrm{ml}$ were sonicated on ice for $60 \mathrm{~s}(4 \times 15 \mathrm{~s})$ and subsequently centrifuged for $20 \mathrm{~min}$ at $20000 \times \mathrm{g}$.

Light-regulated nuclear accumulation of phytochrome A. Five-day-old etiolated seedlings were exposed to red, far-red, blue or white light for $20 \mathrm{~min}$ and after additional $30 \mathrm{~min}$ dark treatment $5 \mathrm{~g}$ of plants was homogenized for nuclei isolation. To $1 \mathrm{ml}$ nuclear protein extract obtained by sonication, $50 \mu \mathrm{l}$ of polyclonal antibodies raised in rabbits against phytochrome A was added. After $30 \mathrm{~min}$ incubation in ice, protein A immobilized on $250 \mu \mathrm{m}$ acrylic beads was used for immunoprecipitation. The pellet obtained after centrifugation was suspended in $100 \mathrm{mM}$ glycine/ $\mathrm{HCl}$ buffer, $\mathrm{pH}$ 2.5. Acrylic beads were centrifuged and the obtained supernatant was analysed by SDS/PAGE and immunobloting.

Immunobloting. SDS/PAGE was performed according to the method of Ogita and Markert (1979) in a Mini Protean II electrophoresis cell (BioRad) using $12 \%(\mathrm{w} / \mathrm{v})$ resolving gel. The molecular mass standard was the $10 \mathrm{kDa}$ Protein Ladder (Gibco). The separated proteins were transferred to a nitrocellulose membrane in buffer containing $50 \mathrm{mM}$ Tris, $380 \mathrm{mM}$ glycine, $0.1 \%(\mathrm{w} / \mathrm{w})$ SDS and 20\% (v/ v) methanol. Positions of the protein markers were visualized by staining with Ponceau S. The blot was incubated with primary antibodies against phytochrome A purified from oat coleoptiles. The position of phytochrome was detected using goat anti-rabbitIgG antibodies (Sigma) conjugated to alkaline phosphatase (Harlow \& Lane, 1988).

Red, far-red or blue light irradiation of coleoptiles. Five-day-old etiolated seedlings were exposed to red, far-red or blue light for $20 \mathrm{~min}$, and after an aditional 30 min dark treatment plants were homogenized for nuclei, etioplasts and postetioplastic fraction separation. The crude nuclear fraction was obtained after $15 \mathrm{~min}$ of centrifugation at $700 \times \mathrm{g}$. Subsequently, the etioplastic fraction was obtained after $2 \mathrm{~min}$ of centrifugation at $6000 \times \mathrm{g}$ as described by Evans and Smith (1976). The obtained supernatant was designated as the postetioplasic fraction.

Isolation and purification of NDPK. The nuclear protein extract was used to purify NDPK directly after it was obtained, whereas proteins con- 
tained in the postnuclear fraction were salted out using ammonium sulphate to $67 \%$ saturation and were stored at $4^{\circ} \mathrm{C}$ until use.

Ion exchange chromatography on DEAESephacel. Nuclear proteins were applied to a column $(2.5 \mathrm{~cm} \times 10 \mathrm{~cm})$ filled with DEAE-Sephacel, equilibrated with $25 \mathrm{mM}$ Tris/ $\mathrm{HCl}$ buffer, $\mathrm{pH} 7.5$, containing $1 \mathrm{mM}$ 2-mercaptoethanol (buffer A). Proteins not bound to the carrier were eluted with buffer A until the absorbance of the eluate at 280 $\mathrm{nm}$ was below 0.1. Proteins bound to the bed were eluted with a linearly increasing chloride ion concentration in buffer A (from 0 to $300 \mathrm{mM} \mathrm{NaCl}$ ) at $0.8 \mathrm{ml} / \mathrm{min}$. Fractions of $6 \mathrm{ml}$ were collected.

Proteins of the postnuclear fraction salted out with ammonium sulfate to $67 \%$ saturation were centrifuged and subsequently dialyzed overnight against buffer $\mathrm{A}$. The clear supernatant obtained after centrifugation of the denatured proteins was applied to a DEAE-Sephacel column equilibrated with buffer A. Proteins not bound to the column were eluted with buffer A, and those bound to DEAESephacel were eluted as above. Proteins remaining on the column were eluted with buffer A containing $300 \mathrm{mM} \mathrm{NaCl}$. Fractions with the highest NDPK activity were pooled and concentrated to $1-3 \mathrm{ml}$ in an Amicon 8050 filtration apparatus (Diaflo YM 10 membrane).

Chromatography on Bio-Gel HTP hydroxyapatite. The NDPK preparation obtained after ion exchange chromatography was applied at $0.4 \mathrm{ml} / \mathrm{min}$ to a hydroxyapatite column $(1.5 \mathrm{~cm} \times 5 \mathrm{~cm})$ equilibrated with buffer A. Proteins not bound to the bed were eluted with buffer A until the absorbance at $280 \mathrm{~nm}$ was less than 0.05 , whereas proteins remaining on the column were eluted with a linearly increasing phosphate ion concentration $(50 \mathrm{ml}$ of buffer $\mathrm{A}$ and $50 \mathrm{ml} 400 \mathrm{mM}(\mathrm{K})$ phosphate buffer, $\mathrm{pH}$ 7.5). Fractions $(6 \mathrm{ml})$ were collected. The fractions with the highest enzyme activity were pooled and concentrated under nitrogen to about $1 \mathrm{ml}$.

Desalting of the enzyme on Sephadex G-10 gel. The concentrated enzyme preparation obtained after adsorption chromatography was applied to a $1.5 \mathrm{~cm} \times 15 \mathrm{~cm}$ Sephadex G-10 column in order to remove phosphates. The proteins were eluted with buffer A, and fractions having NDPK activity were pooled and concentrated to of about $1 \mathrm{ml}$.

Chromatography on GTP-agarose. The enzyme preparation depleted of phosphate ions was applied to a minicolumn containing $1 \mathrm{ml}$ GTP-Agarose equilibrated with $25 \mathrm{mM}$ Tris/ $\mathrm{HCl}$ buffer, $\mathrm{pH}$ 7.5, containing $1 \mathrm{mM}$ 2-mercaptoethanol and $1 \mathrm{mM}$ $\mathrm{MgCl}_{2}$ (buffer B). Proteins not bound to the column were eluted with buffer $B$, whereas proteins remaining on the bed were eluted with $25 \mathrm{mM}$ Tris/ $\mathrm{HCl}$ buffer, $\mathrm{pH}$ 7.5, containing $1 \mathrm{mM}$ 2-mercaptoethanol,
$1 \mathrm{mM} \mathrm{MgCl}{ }_{2}, 25 \mathrm{mM} \mathrm{NaCl}$ and $1 \mathrm{mM} \mathrm{ATP} \mathrm{(buffer}$ C). Three active fractions of $2 \mathrm{ml}$ each were concentrated to about $0.5 \mathrm{ml}$.

Determination of molecular mass of NDPK by molecular filtration on Sephadex G-150. A 2.5 $\mathrm{cm} \times 86 \mathrm{~cm}$ Sephadex G-150 column equilibrated with buffer A was calibrated using the following protein standards: myoglobin (17.6 kDa), chicken egg albumin $(45 \mathrm{kDa})$, bovine serum albumin $(67 \mathrm{kDa})$ and hexokinase $(95 \mathrm{kDa})$. Isoforms of NDPK of the nuclear fraction and the postetioplastic fraction obtained after ion exchange chromatography were then separated on the calibrated column. Proteins were eluted with buffer $\mathrm{A}$ at $0.07 \mathrm{ml} / \mathrm{min}$. Fractions of $1.4 \mathrm{ml}$ were collected and used for NDPK activity assays.

Determination of molecular mass of NDPK isoforms by denaturing electrophoresis. Electrophoresis under denaturing conditions was performed according to Ogita and Markert (1979) using $4 \%(\mathrm{w} / \mathrm{v})$ stacking gel and $16 \%(\mathrm{w} / \mathrm{v})$ separating gel. A mixture of polypeptides (Protein Leadder) obtained from Gibco was used as standards.

Assay of nucleoside diphosphate kinase activity. The method is based on assaying the ADP formed in reaction 1, which in the presence of phosphoenolpyruvate is phosphorylated to ATP by phosphoenolpyruvate kinase (reaction 2), and the pyruvate formed in this reaction is reduced in the presence of NADH by lactate dehydrogenase (reaction 3)

$$
\begin{aligned}
& \mathrm{ATP}+\mathrm{dCDP} \Leftrightarrow \mathrm{ADP}+\mathrm{dCTP} \\
& \mathrm{ADP}+\text { phosphoenolpyrvate }+\mathrm{H}^{+} \Leftrightarrow \begin{array}{c}
\text { (reaction 1), } \\
(\text { reaction } 2),
\end{array} \\
& \text { pyruvate }+\mathrm{NADH}+\mathrm{H}^{+} \Leftrightarrow \text { L-lactate }+\mathrm{NAD}^{+}
\end{aligned}
$$

(reaction 3).

The reaction medium $(1 \mathrm{ml})$ contains: $50 \mathrm{mM}$ Hepes/KOH buffer, pH 7.5, $25 \mathrm{mM} \mathrm{KCl}, 6.25 \mathrm{mM}$ $\mathrm{MgCl}_{2}, 2 \mathrm{mM}$ ATP, $2 \mathrm{mM}$ phosphoenolpyruvate, 0.3 $\mathrm{mM}$ NADH, 1.95 units of pyruvate kinase and 3.75 units of lactate dehydrogenase. After adding the analyzed tissue extract or the NDPK preparation, the hydrolytic activity in respect to ATP was first determined and subsequently $0.5 \mu$ mole of dCDP was added (acceptor of the phosphate residue from ATP, not subject to phosphorylation by pyruvate kinase). The velocity of oxidation of reduced $\mathrm{NADH}_{2}$ in the reaction medium measured spectrophotometrically at $340 \mathrm{~nm}$ is a measure of the velocity of the reaction. The assays were performed at room temperature (Shimadzu UV-Visible Recording Spectrophotometer UV-160A).

Analysis of in vitro effects of phytochrome A on NDPK activity. Phytochrome A was isolated and purified from etiolated oat coleoptiles according 
to Vierstra and Quail (1983). The obtained phytochrome A did not contain NDPK and did not show a hydrolytic activity towards ATP. The effect of phytochrome A on NDPK activity was analyzed in a standard medium used for assays of NDPK to which $50 \mu \mathrm{l}$ of a solution containing purified phytochrome A was added. After determining the initial velocity of the reaction, the cuvette with the analyzed sample was removed from the spectrophotometer, illuminated for $5 \mathrm{~min}$ with red or far red light using a projector with interference filters, and the decrease in absorbance at $340 \mathrm{~nm}$ was measured again. The effect of red and far-red light on the velocity of oxidation of reduced $\mathrm{NADH}$ in a medium without phytochrome A was also checked.

\section{RESULTS AND DISCUSSION}

\section{Subcellular localization of NDPK in etiolated oat seedlings}

Total NDPK activity determined in crude homogenates obtained from etiolated oat seedlings was within the range of 28.9 to $31.5 \mu \mathrm{mol} \mathrm{dCTP} / \mathrm{min}$, and after fractionation of subcellular structures, the total activity of all fractions increased to $31.8-37.5 \mu \mathrm{mol}$ $\mathrm{dCTP} / \mathrm{min}$ (increase by about $5-24 \%$ ). The results of experiments presented in Table 1 and obtained from three repeats indicate that approx. $81-85 \%$ of total NDPK activity occurred in the cytoplasmic fraction, $14-17 \%$ in the mitochondrial + etioplastic fraction, $0.5-1.4 \%$ in the nuclear fraction and about $1 \%$ of the total activity of the analyzed enzyme was associated with the microsomal fraction.

Effects of the red, far-red or blue-light irradiation of coleoptiles on NDPK activity

The results of experiments presented in Table 2 show that in the nuclear fraction obtained from red-light irradiated coleoptiles, NDPK activity $(0.3 \mu \mathrm{mol} \mathrm{dCTP} / \mathrm{min}$ per $10 \mathrm{~g}$ fresh weight) increased by about $42 \%$ as compared with the total enzyme activity in the nuclear fraction isolat-
Table 1. Subcellular localization of NDPK in etiolated oat seedlings.

Values presented in the table are the result of three repeats.

\begin{tabular}{lcc}
\hline Subcellular fraction & $\begin{array}{c}\text { Total activity } \\
(\mu \text { mole dCTP/min) }\end{array}$ & $\begin{array}{c}\text { Fraction of total } \\
\text { activity }(\%)\end{array}$ \\
\hline Nuclear & $0.2-0.5$ & $0.5-1.4$ \\
Mitochondrial + & $4.4-6.3$ & $13.8-16.7$ \\
$\quad$ etioplastic & $0.2-0.3$ & $0.7-0.8$ \\
Microsomal & $27.0-30.4$ & $81.0-84.9$ \\
Cytoplasmic & &
\end{tabular}

ed from coleoptiles grown in darkness $(0.2 \mu \mathrm{mol}$ $\mathrm{dCTP} / \mathrm{min}$ per $10 \mathrm{~g}$ fresh weight). The NDPK activity in the etioplastic and postetioplastic fractions isolated from red-light irradiated coleoptiles increased by about $7 \%$ and $14 \%$, respectively. The enzyme activity in the same subcellular fractions isolated from far-red or blue-light irradiated coleoptiles was nearly identical to that in non-irradiated plants (Table 2).

Light-regulated nuclear import of phytochrome $\mathrm{A}$ in oat coleoptiles

Light-induced nuclear import of phytochrome A was studied by immunoprecipitation using polyclonal antibodies against oat phytochrome A. Etiolated oat coleoptiles exposed for $20 \mathrm{~min}$ to red, farred, blue or white light were excised after a subsequent $30 \mathrm{~min}$ dark period. Protein extracts obtained from isolated nuclear fraction were incubated with antibodies, and the imunocomplexes formed were immunoprecipitated on protein A immobilized on acrylic beads. Pellets separated by centrifugation were dissolved in acidic buffer and after SDS/PAGE separation of proteins, phytochrome A was analysed by immunoblotting. Results shown in Fig. 1. demonstrate that nuclear accumulation of phytochrome A occurs only under red (lane 3), far-red (lane 4), or white light (lane 6) irradiation. The immunoprecipitated phytochrome A is by about $10 \mathrm{kDa}$ smaller than purified phytochrome A preparation (lane 1). In contrast, nuclear fraction isolated from dark-grown

Table 2. Activation of NDPK by red, far red and blue light illumination of oat coleoptiles

\begin{tabular}{|c|c|c|c|c|c|c|}
\hline \multirow{2}{*}{ Subcellular fraction } & \multicolumn{6}{|c|}{$\begin{array}{c}\text { Total activity } \\
(\mu \text { mole } \mathrm{dCTP} / \mathrm{min} \text { per } 10 \mathrm{~g} \text { fresh weight) }\end{array}$} \\
\hline & Dark control & $\begin{aligned} & 15 \text { min red } \\
&+ 30 \text { min dark } \\
&\end{aligned}$ & Dark control & $\begin{array}{l}15 \text { min far red } \\
+30 \text { min dark }\end{array}$ & Dark control & $\begin{array}{r}15 \text { min blue } \\
+30 \text { min dark } \\
\end{array}$ \\
\hline Nuclear & $0.2 \pm 0.0$ & $\begin{array}{c}0.3 \pm 0.1 \\
(142 \%)\end{array}$ & $0.6 \pm 0.1$ & $\begin{array}{c}0.6 \pm 0.1 \\
(100 \%)\end{array}$ & $0.6 \pm 0.1$ & $\begin{array}{c}0.5 \pm 0.0 \\
(82 \%)\end{array}$ \\
\hline Etioplastic & $2.7 \pm 0.5$ & $\begin{array}{c}2.9 \pm 1.0 \\
(107 \%)\end{array}$ & $2.8 \pm 0.6$ & $\begin{array}{c}2.6 \pm 0.3 \\
(93 \%)\end{array}$ & $2.7 \pm 0.3$ & $\begin{array}{c}2.6 \pm 0.3 \\
(99 \%)\end{array}$ \\
\hline Postetioplastic & $22.9 \pm 2.6$ & $\begin{array}{c}26.1 \pm 2.0 \\
(114 \%)\end{array}$ & $15.8 \pm 3.1$ & $\begin{array}{c}17.4 \pm 0.0 \\
(110 \%)\end{array}$ & $16.7 \pm 2.0$ & $\begin{array}{c}17.0 \pm 1.5 \\
(101 \%)\end{array}$ \\
\hline
\end{tabular}




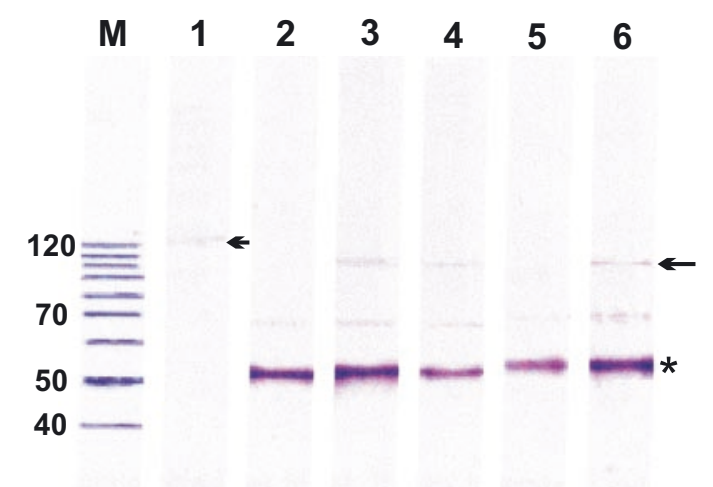

Figure 1. Light-regulated nuclear accumulation of phytochrome A.

Immunoblot analysis of immunocomplexes precipitated on protein A immobilized on acrylic beads. Lane M, molecular mass markers; lane 1, purified phytochrome A; lane 2, coleoptiles from darkness; lane 3, red-light; lane 4, far-red light; lane 5, blue light; lane 6, white light treated coleoptiles. Arrows mark phytochrome A, asterisk marks IgG heavy chain.

(lane 2) or blue light irradiated plants (lane 5) does not contain detectable amounts of phytochrome A.

\section{Isolation of NDPK isoforms regulated by light}

Ion exchange chromatography of proteins of the nuclear fraction

The NDPK elution profile presented in Fig. 2 indicates that cell nuclei of oat coleoptiles contain two isoforms of the enzyme which are easy to separate; the first, further referred to as $\mathrm{I}_{\mathrm{n}^{\prime}}$ elutes from the column at $30 \mathrm{mM}$ chloride ion concentration, whereas the second isoform elutes from the bed only at $110 \mathrm{mM} \mathrm{NaCl}$.

Ion exchange chromatography of proteins from the postnuclear fraction

The elution profile of NDPK shown that the postnuclear fraction contains NDPK isoforms eluted from the column in the form of well-separated peaks of enzymatic activity (Fig. 3). Peak $\mathrm{I}_{\mathrm{pn}}$ is eluted by buffer A, peak $\mathrm{II}_{\mathrm{pn}}$ is eluted by $30 \mathrm{mM}\left[\mathrm{Cl}^{-}\right]$, peak III $_{\mathrm{pn}}$ is released from the column with $110 \mathrm{mM}$ chloride ions and peak $\mathrm{IV}_{\mathrm{pn}}$ was only eluted by $300 \mathrm{mM}$ $\mathrm{NaCl}$.

\section{Identification of NDPK isoforms regulated by phy- tochrome A}

The two nuclear NDPK isoforms and the four isoforms from the postnuclear fraction obtained after DEAE-Sephacel chromatography were analyzed for their susceptibility to activation by phytochrome A. The activity of each NDPK isoform was assayed in a standard reaction medium in the presence of the same amount of photoreversible phytochrome A. In preliminary investigations, we established that phytochrome A purified from oat coleoptiles did not contain NDPK activity and did not hydrolyze ATP (not shown). After determining the initial activity, the cuvette with the analyzed sample was taken out of the spectrophotometer, irradiated with red light $\left(480 \mu \mathrm{mol} \cdot \mathrm{m}^{-2} \cdot \mathrm{s}^{-1}\right)$ or far red light (24 $\left.\mu \mathrm{mol} \cdot \mathrm{m}^{-2} \cdot \mathrm{s}^{-1}\right)$, and the decrease of absorbance at $340 \mathrm{~nm}$ was measured again. In preliminary experiments, we established that irradiation of particular NDPK isoforms with red or far-red light in the absence of phytochrome $\mathrm{A}$ in the reaction medium did not affect the catalytic activity of the enzyme. The changes in NDPK activity observed as a result of irradiation of the samples with red or far-red light in the presence of phytochrome A are presented in Table 3. The obtained results indicate that the $I_{n}$ nuclear isoform of NDPK is distinctly activated by red light in the presence of phytochrome A. The activity of the enzyme is increased over three-fold after 5-min irradiation of the sample. Photoconversion of phytochrome A to the Pr form after irradiation of the same sample with far-red light does not reverse the effect obtained with red light but leads to a further increase of the NDPK enzymatic activity by about $16 \%$.

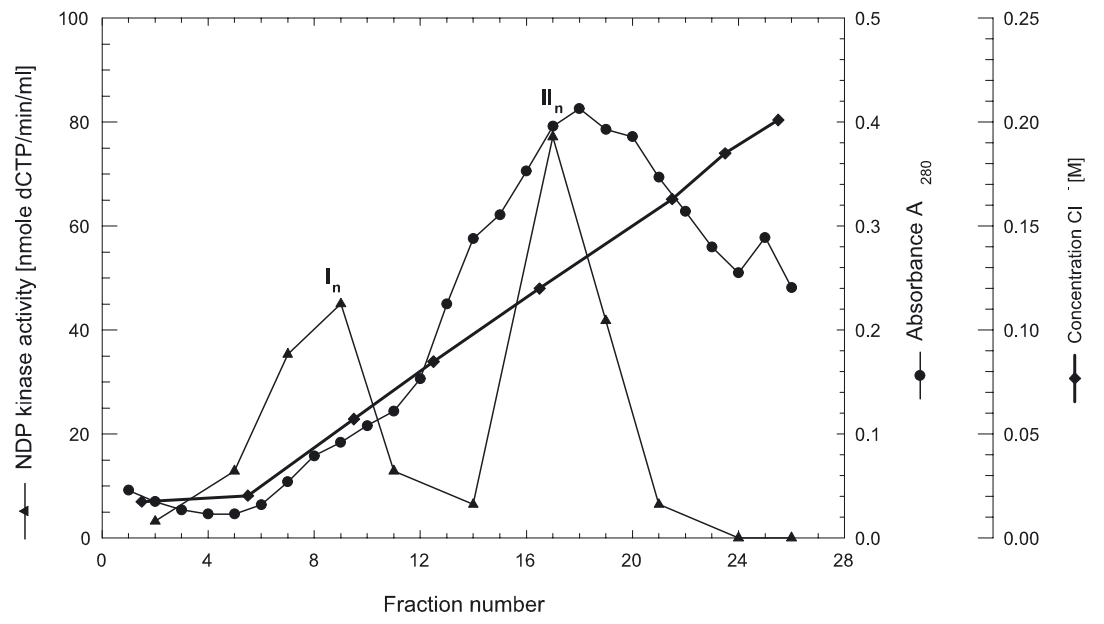

Figure 2. Chromatography on DEAE-Sephacel of nuclear NDPK isoforms.

The $\mathrm{NaCl}$ gradient was from 0 to $300 \mathrm{mM}$. Two NDPK isoforms were eluted at $30 \mathrm{mM}\left(\mathrm{NDPK} \mathrm{I}_{\mathrm{n}}\right)$ and $110 \mathrm{mM}$ (NDPK II ${ }_{n}$ ) $\mathrm{Cl}^{-}$in the buffer, respectively. 
Table 3. Changes in catalytic activity of NDPK isoforms accompanying phytochrome A photoconversion

\begin{tabular}{|c|c|c|c|c|c|c|}
\hline \multirow{3}{*}{ Illumination } & \multicolumn{6}{|c|}{ Activity of NDPK (nmole dCTP/10 min per $50 \mu \mathrm{l}$ ) } \\
\hline & \multicolumn{2}{|c|}{ Nuclear isoforms } & \multicolumn{4}{|c|}{ Postnuclear isoforms } \\
\hline & $\mathrm{I}_{\mathrm{n}}$ & $\mathrm{II}_{\mathrm{n}}$ & $\mathrm{I}_{\mathrm{pn}}$ & $\mathrm{II}_{\mathrm{pn}}$ & $\mathrm{III}_{\mathrm{pn}}$ & $\mathrm{IV}_{\mathrm{pn}}$ \\
\hline None & $\begin{array}{c}11.8 \pm 1.3 \\
(100 \%)\end{array}$ & $\begin{array}{c}30.3 \pm 2.5 \\
(100 \%)\end{array}$ & $\begin{array}{c}17.7 \pm 2.2 \\
(100 \%)\end{array}$ & $\begin{array}{c}24.1 \pm 3.1 \\
(100 \%)\end{array}$ & $\begin{array}{l}6.4 \pm 1.1 \\
(100 \%)\end{array}$ & $\begin{array}{c}19.3 \pm 2.3 \\
(100 \%)\end{array}$ \\
\hline 5 min red light & $\begin{array}{c}35.9 \pm 5.1 \\
(304 \%)\end{array}$ & $\begin{array}{c}29.4 \pm 2.1 \\
(97 \%)\end{array}$ & $\begin{array}{c}19.3 \pm 2.6 \\
(109 \%)\end{array}$ & $\begin{array}{c}32.2 \pm 4.3 \\
(134 \%)\end{array}$ & $\begin{array}{l}6.4 \pm 1.1 \\
(100 \%)\end{array}$ & $\begin{array}{c}19.3 \pm 2.3 \\
(100 \%)\end{array}$ \\
\hline $\begin{array}{l}5 \mathrm{~min} \text { red light/ } \\
5 \mathrm{~min} \text { far-red light }\end{array}$ & $\begin{array}{c}41.6 \pm 4.8 \\
(353 \%)\end{array}$ & $\begin{array}{c}28.5 \pm 1.8 \\
(94 \%)\end{array}$ & $\begin{array}{c}19.3 \pm 1.9 \\
(109 \%)\end{array}$ & $\begin{array}{c}32.2 \pm 3.8 \\
(134 \%)\end{array}$ & $\begin{array}{l}6.4 \pm 1.1 \\
(100 \%)\end{array}$ & $\begin{array}{c}19.3 \pm 2.3 \\
(100 \%)\end{array}$ \\
\hline
\end{tabular}

Analyzing the results shown in Table 3, it is worth noting that besides the nuclear $\mathrm{I}_{\mathrm{n}}$ isoform, only isoform $\mathrm{II}_{\mathrm{pn}}$ from the postnuclear fraction is clearly activated by red light in the presence of phytochrome A. The activity of this isoform increases after irradiation with red light by about $34 \%$ and does not change after photoconversion of phytochrome A to the Pr form. The activity of the other isoforms changed only slightly or not at all after irradiation with red or far-red light and in the presence of phytochrome A (Table 3).

Purification of NDPK isoforms $I_{n}$ and $I_{p n}$ regulated by light

The purification of NDPK isoforms $I_{n}$ and $\mathrm{II}_{\mathrm{pn}}$ essentially encompassed three steps. In the first, the previously described ion exchange chromatography on DEAE-Sephacel was used (Figs. 2 and 3). The concentrated isoform $\mathrm{I}_{\mathrm{n}}$ and $\mathrm{II}_{\mathrm{pn}}$ preparations obtained after ion exchange chromatography were separated using adsorption chromatography. Proteins not bound to hydroxyapatite were eluted with buffer $\mathrm{A}$, whereas proteins adsorbed on the column were eluted with $(\mathrm{K})$ phosphate buffer, $\mathrm{pH} 7.5$, with a linearly increasing phosphate ion concentration from 0 to $400 \mathrm{mM}$. The results of the separation presented in Fig. $4 \mathrm{~A}$ and $4 \mathrm{C}$ indicate that both $\mathrm{I}_{\mathrm{n}}$ and $\mathrm{II}_{\mathrm{pn}}$ isoforms bind relatively strongly to the carrier as they begin to be eluted from the column only at about $170 \mathrm{mM}$ phosphate ion concentration. Samples containing NDPK activity were pooled and concentrated to about $0.5 \mathrm{ml}$, and after removal of phosphate ions on a Sephadex G-10 column, they were subjected to affinity chromatography on GTP-Agarose. Proteins not bound to the column were eluted with buffer A containing $1 \mathrm{mM} \mathrm{MgCl}_{2}$ (buffer B), whereas proteins bound to the bed were eluted with $1 \mathrm{mM}$ ATP in buffer C (Fig. 4B, D).

\section{Electrophoresis in $16 \%$ polyacrylamide gel (SDS/PAGE)}

In order to check the homogeneity of the obtained enzyme preparations and to determine the molecular mass of both NDPK isoforms, electrophoresis under denaturing conditions was performed on a $16 \%$ polyacrylamide gel (SDS/PAGE). In total, $0.87 \mu \mathrm{g}$ of isoform $\mathrm{I}_{\mathrm{n}}$ protein and $0.6 \mu \mathrm{g}$ isoform $\mathrm{II}_{\mathrm{pn}}$ protein were applied to the gel. The appearance of

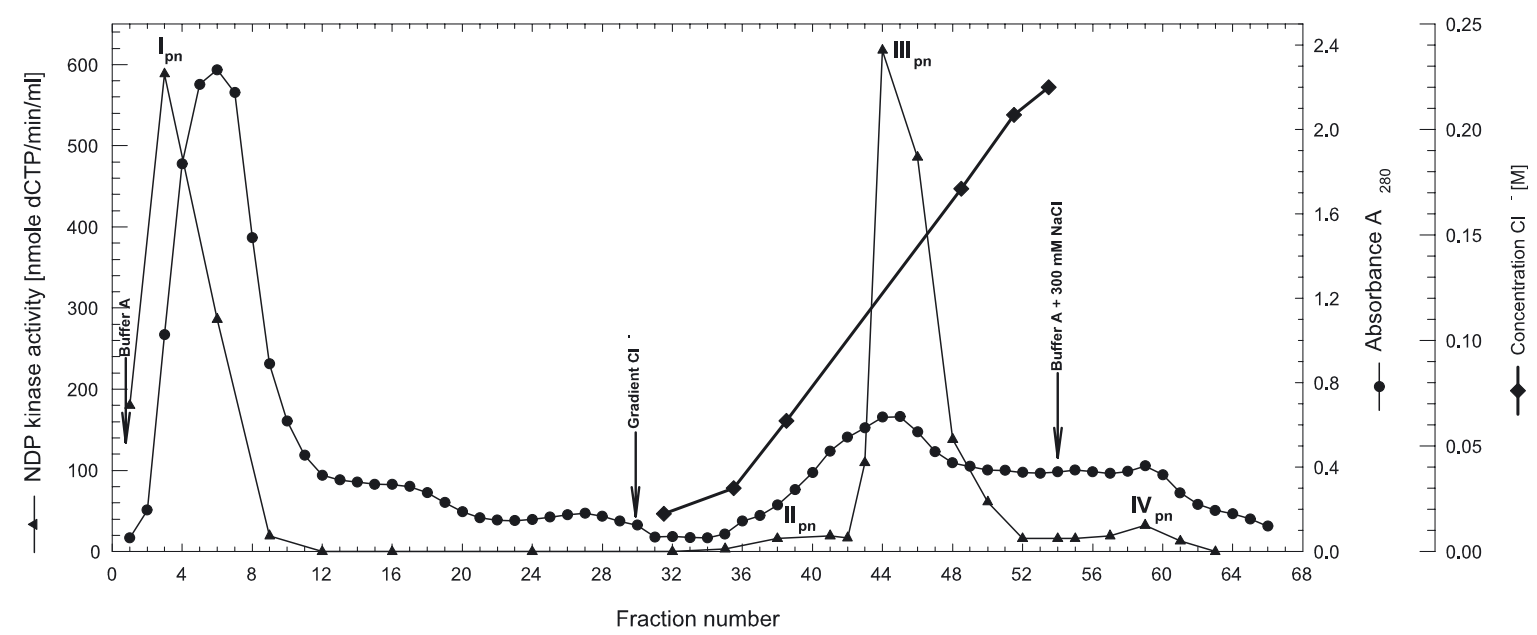

Figure 3. Elution profile of NDPK isoforms from postnuclear fraction.

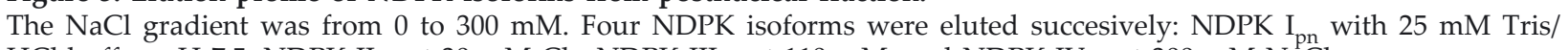
$\mathrm{HCl}$ buffer, pH 7.5; NDPK II ${ }_{\mathrm{pn}}$ at $30 \mathrm{mM} \mathrm{Cl}^{-}$; NDPK III $\mathrm{pn}_{\text {at }} 110 \mathrm{mM}$; and $\mathrm{NDPK} \mathrm{IV}_{\mathrm{pn}}$ at $300 \mathrm{mM} \mathrm{NaCl}$. 
A

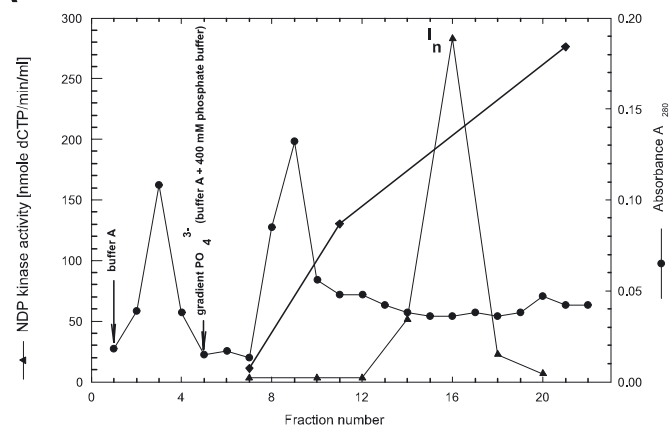

B

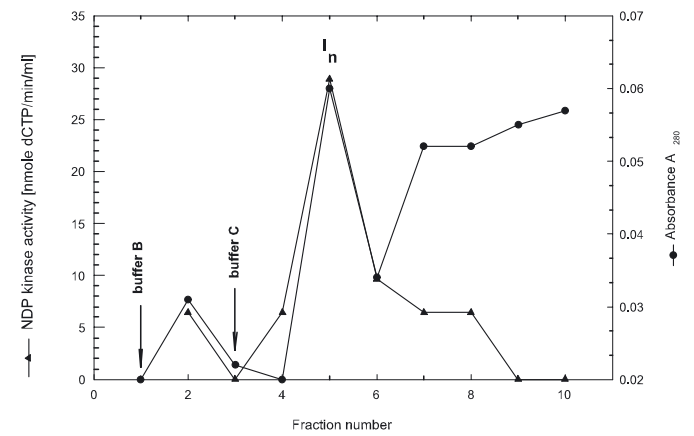

C
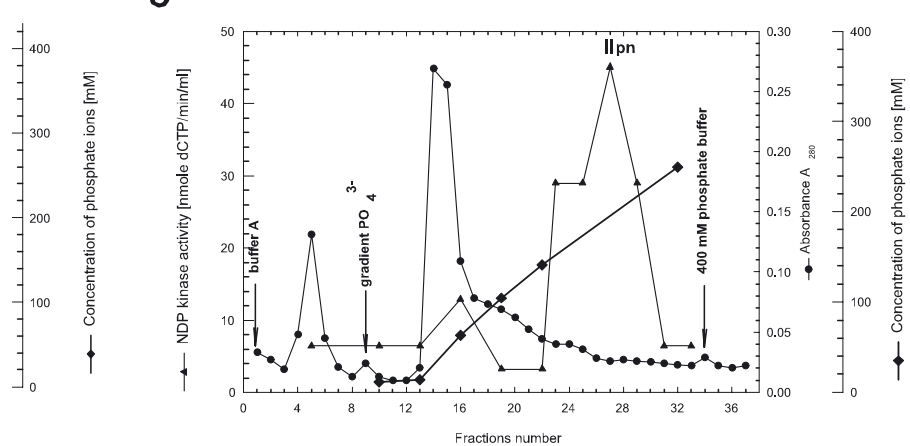

D

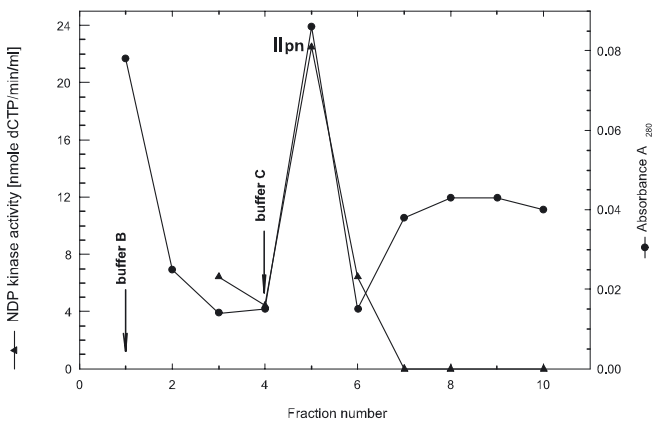

Figure 4. Purification of light-regulated $\mathrm{I}_{\mathrm{n}}$ and $\mathrm{II}_{\mathrm{p}}$ NDPK isoforms.

(A) Adsorption chromatography of isoform $I_{n}$ of NDPK on hydroxyapatite Bio-Gel HTP. (B) Affinity chromatography of isoform $I_{n}$ of NDPK on GTP-Agarose. (C) Adsorption chromatography of isoform $I_{p n}$ of NDPK on hydroxyapatite BioGel HTP. (D) Affinity chromatography of isoform II $_{p n}$ of NDPK on GTP-Agarose.

polypeptides stained with silver presented in Fig. 5 indicates that both enzyme preparations are homogeneous, and the molecular mass of the purified isoforms is similar or identical, $17-18 \mathrm{kDa}$. The molecular mass of the native isoforms $\mathrm{I}_{\mathrm{n}}$ and $\mathrm{II}_{\mathrm{pn}}$ obtained after ion exchange chromatography determined by gel filtration on a Sephadex G-150 column is 71 and

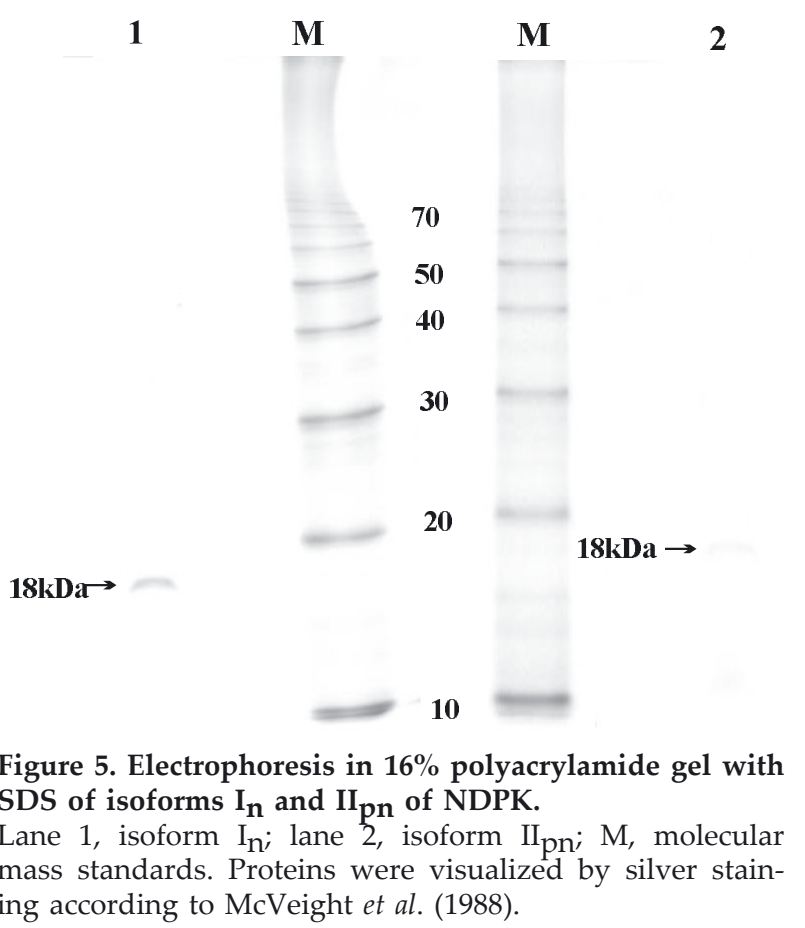

$63 \mathrm{kDa}$, respectively, indicating that both isoforms have a homotetrameric structure with a molecular mass of approx. $68 \mathrm{kDa}$.

In investigations on signal pathways activated by phytochromes, the following proteins have been identified to interact with these photoreceptors: PIFs, HFR/REP1/RSF1, ARR4, ELF, FHY1 (Lorrain et al., 2006; Castillon et al., 2007), and among them also proteins which undergo phosphorylation as a result of such an interaction: PKS1, Aux/IAA, Cry1, NDPK (Kim et al., 2002; Quail, 2002). Our interest in the regulation of NDPK by light through phytochromes follows that this is the only case known to us in which phytochrome A interacts directly with the enzyme protein affecting its catalytic activity. The results of experiments performed on animals, which unequivocally indicate that the role of NDPK in processes occurring in the cell is much broader than it was previously suspected were also important. NDPK, the product of the awd gene plays an important role in the development of D. melanogaster larvae (Lacombe et al., 2000), while human NDP-A kinase encoded by the NM23-H1 gene was identified for the first time as a protein binding to the sequence silencing the PDGF gene (Ma et al., 2002). NDP-B kinase, the product of the human NM23$\mathrm{H} 2$ gene, binds to a site described as $\mathrm{PuF} / \mathrm{CT}$ in the promoter of the c-MYC oncogene (Postel et al., 1993; Engel et al., 1995; Wagner et al., 1997; Hartsough \& Steeg, 2000; Iizuka et al., 2003). Summing up the re- 
sults of relatively numerous investigations, the conclusion may be drawn that some NDPK isoforms are active in regulation of transcription and DNA repair, others participate in the regulation of cell differentiation and yet other NDPK isoforms may play the role of phosphotransferases transferring a phosphate residue to proteins. A number of reports point out to the possibility of interactions of some NDPKs with other proteins, especially various GTP-binding proteins (Kikkawa et al., 1990; Bominaar et al., 1993; Kimura et al., 2000; 2003; Otero, 2000; Baillat et al., 2002; Cuello et al., 2003; Hippe et al., 2003; Narayanan \& Ramaswami, 2003).

The first investigations of NDPK from plant material were based on purifying two isoforms from spinach leaves and subsequently on cloning the genes which encoded them (Nomura et al., 1991; 1992; Zhang et al., 1993). The purified NDPK and NDPKIIs are homohexamers (92-110 kDa) built of polypeptides with a molecular masses of 16 and 18 kDa (Zhang et al., 1993). Lübeck \& Soll (1995) isolated two isoforms with molecular masses 18.5 and $17.4 \mathrm{kDa}$ from pea chloroplasts and from pea and spinach cytoplasm. NDPKIII with a molecular masses of $16.485 \mathrm{kDa}$ localized in the microsomal fraction was also purified (White et al., 1993; Finan et al., 1994; Zhang et al., 1995). NDPK localized in pea mitochondria is synthesized as a 232 -amino-acid polypeptide $(26 \mathrm{kDa})$, from which an 80 -amino-acid fragment $(9 \mathrm{kDa})$ is cleaved off during transport (Escobar Galvis et al., 1999; Struglics \& Hakansson, 1999). In the alga Dunaliella tertiolecta, a polypeptide of a similar size and localized in mitochondria is encoded by a nuclear NDPK gene (Anderca et al., 2002). Recently, the crystal structure of the mitochondrial NDPK was determined and similarly to enzymes from other organisms it turned out to be a homohexamer (Johansson et al., 2004).

The results of investigations performed so far on NDPKs link the functions of various isoforms with plant responses to some stress factors and to light. Using the yeast two-hybrid system with the Cterminal fragment of the A. thaliana NDPK1 gene, a catalase gene product (AtCAT3) whose expression is regulated by light was identified (Zhong et al., 1997; Fukamatsu et al., 2003). UV-B light in A. thaliana activates the expression of the NDPKIa gene encoding a polypeptide containing a lysine residue in positions 113 and 214, which play a key role in interactions with DNA in the human isoforms Nm23-H1 and $\mathrm{H} 2$ (Zimmermann et al., 1999). In yeast gcn4 mutants NDPKIa binds to the promoter of the yeast HIS4 gene coding for one of the enzymes of histidine biosynthesis, activating its expression and reverting the cell phenotype to the wild type (Zimmermann et al., 1999). Investigations have also been performed showing that NDPK may be controlled by light as brief irradiation of fragments of etiolated pea and rice seedlings with red light causes phosphorylation of NDPK linked to plasmatic membranes and localized in the cytoplasm (Hamada \& Hasunuma, 1994; Hamada et al., 1996; 1999; Tanaka et al., 1998; Ogura et al., 1999).

The participation of phytochromes in redlight-induced regulation of NDPK was unequivocally confirmed by Choi et al. (1999). Those authors using the yeast two-hybrid system found that the Cterminal fragment of phytochrome $\mathrm{A}$ in A. thaliana interacts with recombinant $A$. thaliana NDPK2 and that the physical effect of the interaction between the two proteins is a clear activation of NDPK2. The $A$. thaliana ndpk2 mutant growing under continuous farred light shows a number of phenotype changes that resemble changes characteristic for the phy $A$ mutant, whereas in red light $n d p k 2$ is characterized by a lack of opening and greening of the cotyledons, reactions dependent on phytochrome B (Choi et al., 1999).

The results of our experiments indicate that in oat coleoptiles there are several isoforms of NDPK localized mainly in the cytoplasmic fraction as well as in the mitochondrial and etioplastic fractions (altogether about 95\% of total activity). About $1 \%$ of the total NDPK activity was present in the nuclear fraction. It is notable that in the nuclear fraction obtained from red-light irradiated coleoptiles, NDPK activity increases by about $42 \%$ (Table $2)$. We assume that this is a result of light-regulated nuclear import of the phytochrome A-NDPK complex or that a phytochrome-regulated NDPK isoform localized in nuclei is activated upon phytochrome A translocation into the nuclei (Fankhauser \& Chen, 2008). Results shown in Fig. 1 evidence that red, far-red and white light are equally effective in inducing the nuclear accumulation of phytochrome A. On the other hand, only red-light illumination of coleoptiles causes a significant increase of NDPK activity in nuclear fraction (Table 2). These results clearly demonstrated that a phytochome A regulated the NDPK isoform is located in the nuclear fraction.

The total NDPK activity contained in the nuclear fraction is due to two well-separated isoforms of the enzyme (Fig. 2). The isoform eluting from DEAE-Sephacel at $30 \mathrm{mM}$ chloride ion concentration, designated by us as $\mathrm{I}_{\mathrm{n}^{\prime}}$ is clearly activated by phytochrome A in the form of Pfr. Isoform $\mathrm{II}_{\mathrm{n}}$ eluting from DEAE-Sephacel only at 150-200 mM chloride ion concentration is not activated by purified phytochrome A (Table 3). From the postnuclear fraction, only the enzyme contained in the activity peak eluting from the column at $30 \mathrm{mM}$ chloride ion concentration is activated by phytochrome A. Purified NDPK preparations susceptible to phytochrome A activation from cell nuclei and the postnuclear 
fraction have the same monomeric molecular mass $(17-18 \mathrm{kDa})$. The molecular mass determined by gel filtration on a G-150 column is also similar (71 and $63 \mathrm{kDa}$ ), suggesting that the native enzyme is a homotetramer $(68 \mathrm{kDa})$. Taking additionally into consideration the similar conditions of separation on DEAE-Sephacel and hydroxyapatite columns, it can be assumed that the enzyme preparations designated as $I_{n}$ and $I_{p n}$ are essentially the same NDPK isoform localized partly in the nuclei and partly in the cytoplasm. Such a localization may suggest the possibility of shuttling of this NDPK isoform between the cytoplasm and the nucleus, which similarly as in the case of phytochromes may depend on the light conditions and may be strictly linked to the role of NDPK in phytochrome signaling. On the other hand, the results of experiments presented in Table 3 indicate that the activation of NDPK from nuclei and the postnuclear fraction by phytochrome $\mathrm{A}$ in the Pfr form is different. The nuclear enzyme is activated by over $300 \%$, whereas the enzyme from the postnuclear fraction by only $33 \%$. Moreover, the photoconversion of phytochrome $\mathrm{A}$ to the Pr form differently affects the NDPK activity. In the case of the enzyme from the nuclear extract, the farred light did not reverse the effect of red light but increased the enzyme activation by a further $16 \%$, whereas the activity of the enzyme from the postnuclear fraction did not change under these conditions. The observed differences may be explained by the presence of other proteins or other cell components accompanying the NDPKs obtained from the nuclear extract and the postnuclear fraction. The clear NDPK activation in the presence of phytochrome A in the Pfr form should be abolished after irradiation of phytochrome with far-red light (photoconversion of the phytochrome to the Pr form). The lack of such a reversion can be interpreted as a sign of more permanent changes based on, e.g., phosphorylation of the enzyme by phytochrome A and not only on conformational changes caused by a physical interaction between the two proteins. Recent investigations of the interactions of phytochrome A with A. thaliana NDPK2 have demonstrated an important role of the phosphorylation and dephosphorylation of a serine residue in position 598 in phytochrome A, one of several serine residues subject to autophosphorylation or phosphorylation by protein kinases (Kim et al., 2004; Ryu et al., 2005). Phosphoserine-598 dephosphorylation by a specific protein phosphatase PAPP5 allows the interaction of the photoreceptor with NDPK2 (Ryu et al., 2005). Conformational changes taking place in the enzyme because of substrate binding also play a role in the binding of NDPK2 by the C-terminal region of phytochrome A (Im et al., 2004).

\section{Acknowledgements}

We are grateful to Dr. Jacek Kęsy for the antibody against phytochrome A.

\section{REFERENCES}

Anderca MI, Furuichi T, Pinontoan R, Muto S (2002) Identification of a mitochondrial nucleoside diphosphate kinase from green alga Dunaliella tertiolecta. Plant Cell Physiol 43: 1276-1284.

Baillat G, Gaillard S, Castets F, Monneron A (2002) Interactions of phocein with nucleoside-diphosphate kinase, Eps15, and dynamin I. J Biol Chem 277: 18961-18966.

Barthel TK, Walker GC (1999) Inferences concerning the ATPase properties of DnaK and other HSP70s are affected by the ADP kinase activity of copurifying nucleoside-diphosphate kinase. J Biol Chem 274: 3667036678.

Bölter B, Sharma R, Soll J (2007) Localisation of Arabidopsis NDPK2 - revisited. Planta 226: 1059-1065.

Bominaar AA, Molijn AC, Pestel M, Veron M, Van Haastert PJM (1993) Activation of G-proteins by receptor-stimulated nucleoside diphosphate kinase in Dictyostelium. EMBO J 12: 2275-2279.

Castillon A, Shen H, Huq E (2007) Phytochrome interacting factors: central players in phytochrome-mediated light signaling networks. Trends Plant Sci 12: 514-521.

Choi G, Yi H, Lee J, Kwon Y-K, Soh MS, Shin B, Luka Z, Hahn T-R, Song P-S (1999) Phytochrome signalling is mediated through nucleoside diphosphate kinase 2 . Nature 401: 610-613.

Choi G, Kim J-I, Hong S-W, Shin B, Choi G, Blakeslee JJ, Murphy AS, Seo YW, Kim K, Koh E-J, Song P-S, Lee H (2005) A possible role for NDPK2 in the regulation of auxin-mediated responses for plant growth and development. Plant Cell Physiol 46: 1246-1254.

Cuello F, Schulze RA, Heemeyer F, Meyer HE, Lutz S, Jakobs KH, Niroomand F, Wieland T (2003) Activation of heterotrimeric $\mathrm{G}$ proteins by a high energy phosphate transfer via nucleoside diphosphate kinase (NDPK) B and G $\beta$ subunits. J Biol Chem 278: 7220-7226.

Dorion S, Matton DP, Rivoal J (2006) Characterization of a cytosolic nucleoside diphosphate kinase associated with cell division and growth in potato. Planta 224: $108-124$.

Engel M, Veron M, Theisinger B, Lacombe M-L, Seib T, Dooley S, Welter C (1995) A novel serine/threoninespecific protein phosphotransferase activity of Nm23/ nucleoside-diphosphate kinase. Eur J Biochem 234: 200207.

Escobar Galvis ML, Hakansson G, Alexciev K, Knorpp C (1999) Cloning and characterisation of a pea mitochondrial NDPK. Biochimie 81: 1089-1096.

Escobar Galvis ML, Marttila S, Hakansson G, Forsberg J, Knorpp C (2001) Heat stress response in pea involves interaction of mitochondrial nucleoside diphosphate kinase with a novel 86-kilodalton protein. Plant Physiol 26: 69-77.

Evans A, Smith H (1976) Localization of phytochrome in etioplasts and its regulation in vitro of gibberellin levels. Proc Natl Acad Sci USA 73: 138-142.

Fankhauser C, Chen M (2008) Transposing phytochrome into the nucleus. Trends Plant Sci 13: 596-601.

Finan PM, White IR, Redpath SH, Findlay JBC, Millner PA (1994) Molecular cloning, sequence determination and 
heterologous expression of nucleoside diphosphate kinase from Pisum satioum. Plant Mol Biol 25: 59-67.

Fukamatsu Y, Yabe N, Hasunuma K (2003) Arabidopsis NDK1 is a component of ROS signaling by interacting with three catalases. Plant Cell Physiol 44: 982-989.

Hamada T, Hasunuma K (1994) Phytochrome-mediated light signal transmission to the phosphorylation of proteins in the plasma membrane and the soluble fraction of etiolated pea stem sections. J Photochem Photobiol B: Biol 24: 163-167.

Hamada T, Tanaka N, Noguchi T, Kimura N, Hasunuma K (1996) Phytochrome regulates phosphorylation of a protein with characteristics of a nucleoside diphosphate kinase activity in the crude membrane fraction from stem section of etiolated pea seedlings. J Photochem Photobiol B Biol 33: 143-151.

Hamada T, Hasunuma K, Komatsu S (1999) Phosphorylation of proteins in the stem section of etiolated rice seedling irradiated with red light. Biol Pharm Bull 22: 122-126.

Hammargren J, Salinas T, Maréchal-Drouard L, Knorpp C (2007) The pea mitochondrial nucleoside diphosphate kinase cleaves DNA and RNA. FEBS Lett 581: 35073511.

Harlow E, Lane D (1988) Antibodies. A laboratory manual. New York: Cold Spring Harbor Laboratory Press.

Harris N, Taylor JE, Roberts JA (1994) Isolation of a mRNA encoding a nucleoside diphosphate kinase from tomato that is up-regulated by wounding. Plant Mol Biol 25: 739-742.

Hartsough MT, Steeg PS (2000) Nm23/Nucleoside diphosphate kinase in human cancers. J Bioenerg Biomembr 32: 301-308.

Hippe H-J, Lutz S, Cuello F, Knorr K, Vogt A, Jakobs KH, Wieland T, Niroomand F (2003) Activation of heterotrimeric $G$ proteins by a high energy phosphate transfer via nucleoside diphosphate kinase (NDPK) B and G $\beta$ subunits. J Biol Chem 278: 7227-7233.

Hurkman WJ, Dupont FM, Altenbach SB, Combs A, Chan R, Tanaka CK, Reuveni M, Bernardin JE (1998) BiP, HSP70, NDK and PDI in wheat endosperm. II. Effects of high temperature on protein and mRNA accumulation. Physiol Plant 103: 80-90.

Iizuka N, Mori N, Tamesa T, Tangoku A, Oka M (2003) Telomerase activity and $\mathrm{Nm} 23-\mathrm{H} 2$ protein expression in hepatocellular carcinoma. Anticancer Res 23: 43-48.

Im YJ, Kim J-I, Shen Y, Na Y, Han Y-J, Kim S-H, Song P-S, Eom SH (2004) Structural analysis of Arabidopsis thaliana nucleoside diphosphate kinase-2 for phytochromemediated light signaling. J Mol Biol 343: 659-670.

Johansson M, Mackenzie-Hose A, Andersson I, Knorpp C (2004) Structure and mutational analysis of plant mitochondrial nucleoside diphosphate kinase. Identification of residues involved in serine phosphorylation and oligomerization. Plant Physiol 136: 3034-3042.

Kikkawa S, Takahashi K, Takahashi K-I, Shimada N, Ui M, Kimura N, Katada T (1990) Conversion of GDP into GTP by nucleoside diphosphate kinase on the GTPbinding proteins. J Biol Chem 265: 21536-21540.

Kim J-I, Kozhukh GV, Song P-S (2002) Phytochrome-mediated signal transduction pathways in plants. Biochem Biophys Res Commun 298: 457-463.

Kim J-I, Shen Y, Han Y-J, Park J-E, Kirchenbauer D, Soh M-S, Nagy F, Schafer E, Song P-S (2004) Phytochrome phosphorylation modulates light signaling by influencing the protein-protein interaction. Plant Cell 16: 26292640.

Kimura N, Shimada N, Fukuda M, Ishijima Y, Miyazaki H, Ishii A, Takagi Y, Ishikawa N (2000) Regulation of cellular functions by nucleoside diphosphate kinases in mammals. J Bioenerg Biomembr 32: 309-315.

Kimura N, Shimada N, Ishijima Y, Fukuda M, Takagi Y, Ishikawa N (2003) Nucleoside diphosphate kinases in mammalian signal transduction systems: Recent development and perspective. J Bioenerg Biomebr 35: 41-47.

Lacombe M-L, Milon L, Munier A, Mehus JG, Lambeth DO (2000) The human Nm23/nucleoside diphosphate kinases. J Bioenerg Biomembr 32: 247-258.

Leung S-M, Hightower LE (1997) A 16-kDa protein functions as a new regulatory protein for Hsc70 molecular chaperone and identified a member of the Nm23/nucleoside diphosphate kinase family. J Biol Chem 272: 2607-2614.

Lorrain S, Genoud T, Fankhauser C (2006) Let there be light in the nucleus! Curr Opin Plant Biol 9: 509-514.

Lübeck J, Soll J (1995) Nucleoside diphosphate kinase from pea chloroplasts: purification, cDNA cloning and import into chloroplasts. Planta 196: 668-673.

Ma D, Xing Z, Liu B, Pedigo NG, Zimmer SG, Bai Z, Postel EH, Kaetzel DM (2002) NM23-H1 and NM23-H2 repress transcriptional activities of nuclease-hypersensitive elements in the platelet-derived growth factor-A promoter. J Biol Chem 277: 1560-1567.

McVeigh T, Caffrey P, Owen P (1988) Silver staining of proteins and lipopolysaccharides in SDS-polyacrylamide gels. In Immunochemical and molecular genetics analysis of bacterial photogens, Owen P, Foster TJ eds, pp 267-279. Elsevier Science Publishers.

Moisyadi S, Dharmasiri S, Harrington HM, Lukas TJ (1994) Characterization of a low molecular mass autophosphorylating protein in cultured sugarcane cells and its identification as a nucleoside diphosphate kinase. Plant Physiol 104: 1401-1409.

Moon H, Lee B, Choi G, Shin D, Prasad DT, Lee O, Kwak S-S, Kim DH, Nam J, Bahk J, Hong JC, Lee SY, Cho MJ, Lim CO, Yun D-J (2003) NDP kinase 2 interacts with two oxidative stress-activated MAPKs to regulate cellular redox state and enhances multiple stress tolerance in transgenic plants. Proc Natl Acad Sci USA 100: 358-363.

Narayanan R, Ramaswami M (2003) Regulation of dynamin by nucleoside diphosphate kinase. J Bioenerg Biomembr 35: 49-55.

Nomura T, Fukui T, Ichikawa A (1991) Purification and characterization of nucleoside diphosphate kinase from spinach leaves. Biochim Biophys Acta 1077: 47-55.

Nomura T, Yatsunami K, Honda A, Sugimoto Y, Fukui T, Zhang J, Yamamoto J, Ichikawa A (1992) The amino acid sequence of nucleoside diphosphate kinase I from spinach leaves, as deduced from the cDNA sequence. Arch Biochem Biophys 297: 42-45.

Ogita Z-I, Markert CL (1979) A miniaturized system for electrophoresis on polyacrylamide gels. Anal Biochem 99: 233-241.

Ogura T, Tanaka N, Yabe N, Komatsu S, Hasunuma K (1999) Characterization of protein complexes containing nucleoside diphosphate kinase with characteristics of light signal transduction through phytochrome in etiolated pea seedlings. Photochem Photobiol 69: 397-403.

Otero AS (2000) NM23/Nucleoside diphosphate kinase and signal transduction. J Bioenerg Biomembr 32: 269-275.

Parks RE Jr, Agarwal RP (1973) Nucleoside diphosphokinases. In The Enzymes, Boyer PD ed, vol 8, pp 370-344. Academic Press, New York.

Postel EH, Berberich SJ, Flint SJ, Ferrone CA (1993) Human c-myc transcription factor $\mathrm{PuF}$ identified as $\mathrm{nm} 23-\mathrm{H} 2$ nucleoside diphosphate kinase, a candidate suppressor of tumor metastasis. Science 261: 478-480. 
Quail PH (2002) Phytochrome photosensory signaling networks. Nat Rev 3: 85-93.

Ryu JS, Kim J-I, Kunkel T, Kim B-C, Cho DS, Hong SH, Kim S-H, Fernandez AP, Kim Y, Alonso JM, Ecker JR, Nagy F, Lim PO, Song P-S, Schafer E, Nam HG (2005) Phytochrome-specific type 5 phosphatase controls light signal flux by enhancing phytochrome stability and affinity for a signal transducer. Cell 120: 395-406.

Struglics A, Hakansson G (1999) Purification of a serine and histidine phosphorylated mitochondrial nucleoside diphosphate kinase from Pisum sativum Eur J Biochem 262: 765-773.

Tanaka N, Ogura T, Noguchi T, Hirano H, Yabe N, Hasunuma K (1998) Phytochrome-mediated light signal are transduced to nucleoside diphosphate kinase in Pisum satioum L. cv. Alaska. J Photochem Photobiol B: Biol 45: 113-121.

Vierstra RD, Quail PH (1983) Purification and initial characterization of 124-kilodalton phytochrome from Avena. Biochem 22: 2498-2505.

Wagner PD, Steeg PS, Vu N-D (1997) Two-component kinase like activity of $\mathrm{nm} 23$ correlates with its motility-suppressing activity. Proc Natl Acad Sci USA 94: 9000-9005.

White IR, Finan PM, Millner PA (1993) Nucleoside diphosphate kinase associated with Pisum sativum microsomal membranes: apparent binding of GTP S at nM concentration. J Plant Physiol 142: 191-196.

Yang KA, Moon H, Kim G, Lim CJ, Hong JC, Lim CO, Yun D-J (2003) NDP kinase 2 regulates expression of antioxidant genes in Arabidopsis. Proc Japan Acad 79: 86-91.

Zhang J, Nomura T, Yatsunami K, Honda A, Sugimoto Y, Moriwaki T, Yamamoto J, Ohta M, Fukui T, Ichikawa A (1993) Nucleotide sequence of the cDNA encoding nucleoside diphosphate kinase II from spinach leaves. Biochim Biophys Acta 1171: 304-306.

Zhang J, Fukui T, Ichikawa A (1995) A third nucleoside diphosphate kinase from spinach leaves: purification, characterization and amino-acid sequence. Biochim Biophys Acta 1248: 19-26.

Zhong HH, Resnick AS, Straume M, Mcclung CR (1997) Effects of synergistic signaling by phytochrome A and cryptochrome 1 on circadian clock-regulated catalase expression Plant Cell 9: 947-955.

Zimmermann S, Baumann A, Jaekel K, Marbach I, Engelberg D, Frohnmeyer H (1999) UV-responsive genes of Arabidopsis revealed by similarity to the Gcn4-mediated UV response in yeast. J Biol Chem 274: 17017-17024. 